\title{
Revitalisasi Kelompok Wanita Tani (KWT) melalui Pemanfaatan Pekarangan Rumah di Desa Metesih Kecamatan Jiwan Kabupaten Madiun
}

\author{
Amal Taufiq, Habib.R. \\ UIN Sunan Ampel Surabaya \\ amal taufiq@yahoo.co.id
}

\begin{abstract}
Farmer Women Groups (KWT/Kelompok. Wanita Tani) is one of the organizations in Metesih Village, Jiwan Sub-District, Madiun Regency, East Java, KWT is present in the community to mobilize assets. When students arrived in the village, KWT was empty towards a leadership transition, after students carried out asset mapping, they found many assets, one of the most significant was an organization called KWT. All components of the community agreed to revitalize KWT with its revitalization main program, because by revitalization of KWT belping to strengthen the role of women in people live who had been considered weak, women could not find economic income for their families, with the strengthening of KWT role everything had changed. ABCD (Asset Based Community Development) was used in this research, because this approach was in accordance with the character of the community. Finally, the results obtained from this process namely changing in community mindsets, strengthening the role of KWT in community, increasing the role of women in various sectors and increasing community economic income from corn harvest in their fields.
\end{abstract}

Keywords: KWT, $A B C D$ (Asset Based Community Driven Development)

\section{Pendahuluan}

Pada dasarnya, pembangunan suatu negara jelas bertujuan untuk meningkatkan kesejahteraan atau peningkatan kualitas hidup masyarakatnya, baik itu laki-laki maupun perempuan, meskipun dalam setiap proses pembangunan mempunyai beragam pendekatan. Peningkatan kesejahteraan ini tentunya tidak hanya pada satu aspek pembangunan, tetapi juga merata di segala sendi, baik secara ekonomi, politik, hukum, sosial, budaya dan keamanan. ${ }^{1}$

Untuk mewujudkan kesejahterann masyarakat perlu ada peningkatan skill dan ketrampilan yang memadai khususnya kelompok perempuan, karena selama ini yang banyak terlibat dalam kegiatan-kegiatan peningkatan ekonomi adalah kelompok laki-laki, maka sudah saatnya kelompok perempuan mendapat perhatian yang serius dari berbagai pihak baik dari pemerintah maupun dari institusi lain.

Upaya-upaya untuk pemberdayaan perempuan cukup signifikan untuk dilakukan, dengan

\footnotetext{
${ }^{1}$ Eko Bambang Subiyantoro, Sensitivitas Gender Kebijakan Pemerintaban Sby (Jakarta: The Indonesian Institute, 2005), http://www.theindonesianinstitute.com/wp-content/uploads/2014/02/11-POLICY-ASSESSMENT-SensitivasGender-oleh-Eko-Bambang-Subiyantoro-Juni-2005.pdf.
}

Volume 2, Number 2, November 2018 | 204 Revitalisasi Kelompok Wanita Tani (KWT) melalui Pemanfaatan Pekarangan Rumah di Desa Metesih Kecamatan Jiwan Kabupaten Madiun 


\section{ENGAGEMENT}

Gurnal Pengabdian Kepada Masyarakat

ISSN : 2579-8375 (Print)

ISSN : 2579-8391 (Online)

alasan sebagai berikut, Pertama, ${ }^{2}$ proses pembangunan Indonesia yang menekankan pertumbuhan ekonomi dan modernisasi sejauh ini belum berpihak kepada kepentingan kaum perempuan. Pengalaman kita menerapkan kebijakan pembangunan berorientasi pertumbuhan di dalam bidang pertanian yang ditandai dengan masuknya Revolusi Hijau pada satu sisi pernah meningkatkan posisi Indonesia dari negara pengimpor beras menjadi negara berswasembada pangan. Namun keberhasilan itu harus mengorbankan perempuan.

Kedua, Meski saat ini pengakuan secara normatif terhadap hak-hak perempuan semakin kuat, pengakuan secara formalitas ternyata tidak secara otomatis diiringi dengan implementasi secara sungguh-sungguh di lapangan, hingga kini masih sering kali dijumpai maraknya praktik dsikriminasi atau ketidakadilan dalam memperlakukan kaum perempuan. Sebagai bukti pada sektor pekerjaan modern masih ada praktik secara terselubung yang memarginalkan kaum perempuan dengan menempatkannya pada second sex atau warga kelas dua.

Ketiga, Belum stirilnya kultur sehari-hari kita dari stereotipe atau pelabelan terhadap kelompok perempuan yang cenderung memarginalkan perempuan, gambaran stereotipe itu adalah perempuan adalah seorang yang lemah, emosional, sensitif, tergantung, pasif, submisif, luwes, memerlukan perlindungan dan sebagainya. ${ }^{3}$ Melalui streotipe itu seringkali digambarkan bahwa perempuan adalah orang yang berkiprah dalam sektor domestik, sedangkan laki-laki adalah orang yang berada di jajaran sektor publik. ${ }^{4}$

Ketika mahasiswa terjun ke lokasi KKN transformatif melauli Rapid Rural Apraisal (RRA) ditemukan satu aset institusi yang ada di desa Metesih Kecamatan Jiwan kabupaten Madiun yang anggotanya terdiri dari kaum perempuan. KW'T (Kelompok Wanita Tani) menurut cerita mahasiswa setelah proses wawancara, dahulu KWT dengan semangat dan penuh optimisme memperjuangkan nasib kaum perempuan di desanya. KWT menjadi fenomena yang menarik karena gagasan-gagasannya yang melampaui standar pemikiran-orang-orang desa waktu itu yang secara kultural lekat dengan pameo perempuan konco wingking, kelas dua, dan seterusnya, namun dengan keberadaan KWT semua hal diatas bisa diminimalisir. Namun seiring berjalannya waktu dengan adanya masa transisi kepemimpinan maka selama kurang lebih satu tahun KWT di desa Metesih mengalami kevakuman.

Kelompok Wanita Tani yang menjadi bagian dari kelompok tani di desa Metesih terbentuk karena adanya program yang dicanangkan oleh KPML (Kawasan Rumah Makan Lestari). Selain

\footnotetext{
2 Zubaedi, Pengembangan Masyarakat (Jakarta: Kencana Prenada Media Group, 2013). 230

3 SC Utami.. Munandar, "Kemitrasejajaran, Perspektif Psikologis," in W acana Perempuan Dalam Keindonesiaan Dan Kemodernan, ed. Bainar (Jakarta: Cides. Munandar SC Utami, 1995). 54.

${ }^{4}$ Abdullah Irawan, Sangkan Peran Jender (Yogyakarta: Pustaka palajar untuk PKK UGM, 1997).
} 
itu, adanya dana yang menjadi kebutuhan utama dalam menjalankan suatu program juga menjadi bagian dari Kelompok Wanita Tani bisa terbentuk.

Dalam kehidupan sehari hari masyarakat desa Metesih dari berbagai kelompok masyarakat seperti KWT, PKK, perangkat desa diketahui bahwa aktivitas domestik keluarga bisa dilakukan secara bersama-sama atau bergantian, namun dalam hal pekerjaan wanita belum mendapat porsi yang sama untuk mencari income keluarga.

Warga masyarakat Desa Metesih mempunyai sistem utama dan subsistem yang bisa menjadi pendukung dalam menyeimbangkan sistem utama. Hal ini dikarenakan bahwa sistem pemerintahan desa Metesih seperti struktur kepengurusan desa, kepada desa sebagai sistem utama sedangkan sekretaris desa, kepala dusun, dan ketua RT sebagai bagian dari sistem utama (subsistem). Dari berbagai macam bagian yang terdapat dalam struktur kepengurusan desa Metesih tersebut, keikutsertaan laki-laki lebih dominan dibandingkan perempuan. Hal ini diketahui dari jumlah anggota kepengurusan yang telah disebutkan sebelumnya yaitu 39 (tiga puluh sembilan) orang, terdiri dari 2 (dua) perempuan dan 37 (tiga puluh tujuh) laki-laki. Dari jumlah tersebut menunjukkan bahwa peran perempuan dalam aktivitas sosial di bidang pemerintah masih sangat minim.

Melihat keadaan diatas bagaimana peran KWT beberapa tahun sebelumnya mengalami kesuksesan dan hanya karena adanya transisi kepemimpinan berdampak pada kevakuman dan sekaligus untuk menggerakkan partisipasi khususnya dari kaum paerempuan dalam peran-peran sosial dan juga upaya peningkatan ekonomi rumah tangga yaitu bertambahnya income keluarga maka revitalisasi KWT menjadi penting, tentu ini menjadi harapan dan keingainan khususunya para kaum perempuan yang terlibat langsung dalam kegiatan-kegiatan KW'T dan juga masyarakat desa Metesih agar bisa mengulangi kesuksesan masa lalu (succces story) dan bisa menjadi inspirasi bagi kaum perempuan di seda-desa lain.

\section{Metode}

Ada banyak sekali metode dan cara dalam proses pemberdayaan masyarakat, meskipun banyak ragam pemberdayaan tetapi semua metode itu memiliki beberapa persamaan diantaranya adalah pada tujuan akhirnya. Tujuan akhir dari semua metode adalah adanya "chage" atau perubahan pada masyarakat. Perubahan bisa dilihat dari banyak aspek bisa aspek fisik maupun aspek psikis, seperti perubahan "mindset", perubahan di bidang perekonomian atau kesejahteraan, perubahan dalam partisipasi, perubahan dalam kemandirian dan sebagainya. 
Dalam pengabdian kepada masyarakat yang kami lakukan bersama mahasiswa di desa Metesih Kecamatan Jiwan Kabupaten Madiun ini khususunya pada kelompok Wanita Tani kami menggunakan pendekatan Asset Based Community Driven Development (ABCD). Pendekatan berbasis aset memasukkan cara pandang baru yang lebih holistik dan kreatif dalam melihat realitas, seperti: melihat gelas setengah penuh; mengapresiasi apa yang bekerja dengan baik di masa lampau; dan menggunakan apa yang kita miliki untuk mendapatkan apa yang kita inginkan ${ }^{5}$

Jadi ABCD mengenalkan perspektif baru dalam menyikapi dan merespon realitas di masyarakat. Dalam realitas kehidupan masyarakat selalu ada dua perspektif. Ada kelebihan ada kekurangan, ada permasalahan tapi ada juga potensi yang selalu embeded atau melekat pada diri seeorang atau masyarakat yang dibaratkan sebuah gelas yang berisi air setengah, maka tergantung orang melihat gelas itu, orang bisa mengatakan setengah kosong atau bisa juga setengah isi.

ABCD melihat pada kondisi yang kedua yaitu gelas setengah isi, seberapapun isinya, apa pun jenis airnya, dan bagaimanapun keadaan air itu tidak penting, yang penting ada air dan bagaimanakah menggerakkan air itu agar bisa berguna, dalam kontek individu atau pun masyarakat siapapun orangnya, masayarakat apapun dimana pun pasti memiliki potensi atau asset yang melekat padanya.

"Every single person has capacities, abilities, gifts and ideas, and living a good life depends on whether those capacities can be used, abilities expressed, gifts given and ideas shared". (Jody Kretzmann) ${ }^{6}$

Diantara prinsip ABCD adalah "no body has nothing" tak seorang pun yang tidak memiliki sesuatu, sekecil apa pun pasti seseorang termasuk kelompok perempuan yang mungkin secara kultural mereka diannggap konco wingking memiliki sesuatu yang bisa dikontribusikan pada sesamanya atau ke masyarakat. "every body has anything".

Saat perempuan terorganisir untuk berkontribusi pada ekonomi keluarga atau keseluruhan ekonomi komunitas misalnya, maka semua pihak akan mendapat manfaat. Cara pandang baik dari diri perempuan sendiri akan berubah mereka lebih confident merasa berguna bagi orang lain, dari sisi orang lain maka orang akan memberi apresiasi, muncul rasa saling menghormati satu sama lain. Kondisi seperti ini perlu dikembangkan dengan mengakui potensi perempuan bukan saja untuk kegiatan sosial ekonomi, tetapi juga dalam pengambilan keputusan dan kepemimpinan di ruang publik agar kesetaraan gender bisa seimbang, bersama-sama mengembangkan masyarakat sesuai

\footnotetext{
${ }^{5}$ Christopher Dureau, Pembaru Dan Kekuatan Lokal Untuk Pembangunan, TT: Australian Community Development and Civil Society Strengthening Scheme (ACCESS) Phase II, 2013., 2.

6 Alison Mathie and Gord Cunningham, “Mobilizing Assets for Community-Driven Development,” Participant manual (2008).
} 


\section{ENGAGEMENT}

Gurnal Pengabdian Kepada Masyarakat

ISSN : 2579-8375 (Print)

ISSN : 2579-8391 (Online)

dengan potensi yang dimiliki masing-masing.

\section{ABCD Suatu Pendekatan}

Pendekatan ABCD merupakan pendekatan yang mengarah pada pemahaman dan internalisasi asset, potensi, kekuatan, dan pendayagunaannya secara mandiri dan maksimal. ${ }^{7}$

Dengan pendekatan ABCD yang dilakukan di Desa Metesih Kecamatan Jiwan Kabupaten Madiun sejak tanggal 17 Juli - 16 Agustus 2018 diketahui terdapat potensi atau asset yang ada di wilayah ini, baik aset individual, aset institusional, aset fisik, aset ekonomi, aset sosial, dan sebagainya.

\section{Prinsip-Prinsip (ABCD)}

Metode Asset-Based Community Development (ABCD) mempunyai prinsip-prinsip yang menjadi acuan sekaligus distingsi bagi pengembangan dan pemberdayaan masyarakat. Terkait dengan konteks internalisasi asset, potensi, kekuatan, serta pendayagunaan secara mandiri dan maksimal terhadap masyarakat yang dilakukan secara simultan dan berkesinambungan sehingga hal ini akan menunjukkan berhasil atau tidaknya metode yang diterapkan. Berikut adalah prinsip-prinsip metode ABCD;

a. Setengah terisi lebih berarti (Half Full and Half Empty)

Prinsip ini menjelaskan bahwa kekurangan yang biasa dianggap oleh masyarakat sebagai masalah merupakan suatu hal penting yang harus diubah. Hal ini karena, pengubahan pola pikir masyarakat terutama individu merupakan faktor utama dalam pengembangan asset yang ada di dalamnya.

b. Semua Punya Potensi (No body has nothing)

Prinsip ini menyatakan setiap manusia terlahir dan memiliki kemampuan yang berbeda, tidak ada yang tidak memiliki potensi, walaupun hanya kemampuan yang standart, semua itu meruupakan potensi dan akan berkontribusi, tidak ada alasan bagi seluruh makhluk hidup untuk tidak berkontribusi nyata terhadap perubahan yang lebih baik, bahkan, keterbatasan fisik pun sama sekali tidak menjadi alasan untuk tidak bisa berkontribusi, karena hal itulah bisa menjadi suatu inspirasi bagi masyarakat lain.

c. Partisipasi (Participation)

Prinsip ini merupakan suatu keterlibatan mental dan emosi seseorang untuk mencapai sebuah tujuannya dan ikut bertangguing jawab dalam hal itu, partisipasi, merupakan peran serta seseorang atau kelompok dalam membentuk suatu proses yang baik dengan bentuk pernyataan

\footnotetext{
${ }^{7}$ Nadhir Salahuddin, "Panduan KKN ABCD UIN Sunan Ampel Surabaya Asset Based Community-Driven Development (ABCD)” (Surabaya: LP2M UIN Sunan Ampel Surabaya, 2015). 26.
} 
ataupun kegiatan melalui fikiran, tenaga, ataupun materi yang mereka miliki, serta ikut memanfaatkan dan menikmati hasil-hasil pembangunan.

d. Kemitraan (Partnership)

Kemitraan merupakan hubungan yang dibangun antara beberapa individu atau kelompok yang didasari oleh kerjasama dan tanggung jawab yang sama dalam menggapai suatu tujuan dengan adanya kesepakatan diantara mereka. Partnership merupakan salah satu prinsip utama dalam pendekatan pengembangan masyarakat yang berbasis aset (Asset Based Community Development).

e. Penyimpangan Positif (Positive Deviance)

Penyimpangan positif merupakan sebuah pendekatan terhadap perubahan perilaku individu dan sosial yang didasarkan pada situasi out off the box. Suatu yang ada di masyarakat yang mungkin berbeda dengan kebanyakan masyarakat tetapi merupakan hal yang baik dan berdampak bagi masyarakat.

f. Berawal dari Masyarakat (Endogenous)

Istilah endegenous merupakan pembangunan yang dikembangkan oleh masyarakat sendiri, dalam penggunaannya, kata-kata endegenous seringklai digunakan untuk mensifati pembangunan, sehingga yang sering muncul ialah istilah local endegenous dan istilah pembangunan endogen, pembangunan endogen mengandung arti pembangunan yang berdasar dari dalam konteks atau komunitas tertentu yang dikembangkan dari dalam masyarakat.

\section{Teknik Memfasilitasi Komunitas}

Apresiatif Inquiri (AI) adalah salah satu teknik yang digunakan dalam ABCD. AI disini dimaknai sebagai pengakuan dan peningkatan nilai. Ini adalah masalah penegasan apresiasi terhadap kesuksesan masa lalu (succes story) dan saat ini, pengakuan terhadap aset-aset dan potensipotensi yang dimiliki. Dengan menggunakan wawancara apresiatif diharapkan dapat memunculkan memori positif pada individu dan masayarakat.

AI menganggap bahwa organisasi meningkat efektifitasnya melalui penemuan, penghargaan, impian, dialog dan membangun masa depan bersama. Proses Appreciative Inquiry (Model 4-D) yaitu (Discovey, Dream, Design dan Destiny) 


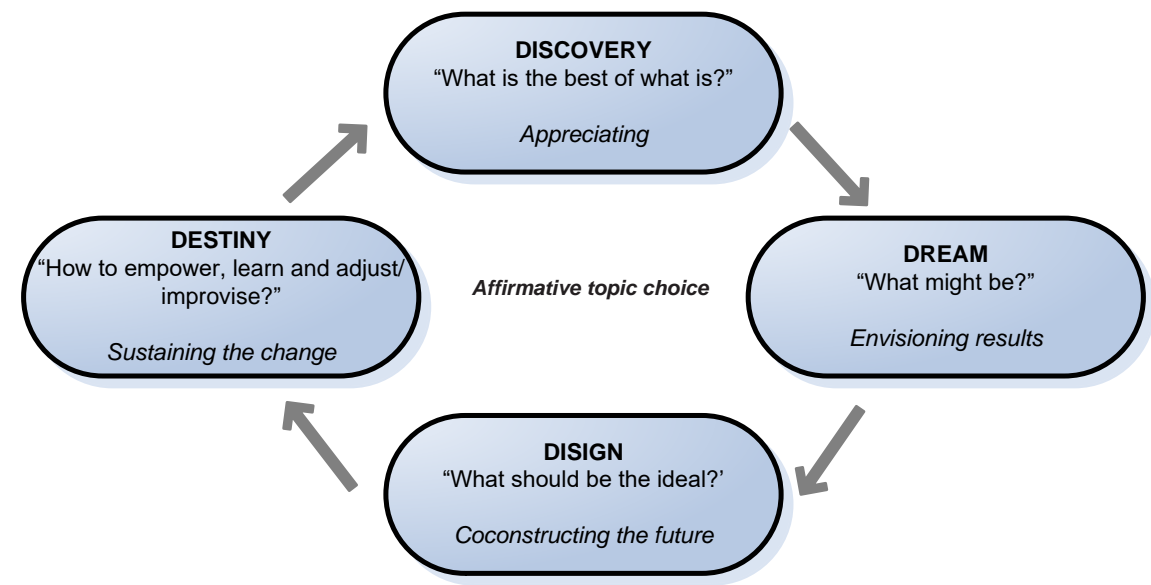

Gambar 1. Siklus dalam ABCD

Discovery, adalah tahap proses pencarian yang mendalam tentang hal-hal positif, hal-hal terbaik yang pernah dicapai, dan pengalaman-pengalaman keberhasilan di masa lalu. Proses ini dilakukan dengan wawancara appresiatif memetakan aset memalui indivdual inventory, transek, leacku bucket dan sebagainya.

Dream, berdasarkan informasi yang diperoleh dari tahap sebelumnya, orang kemudian mulai membayangkan masa depan yang diharapkan. Pada tahap ini, setiap orang mengeksplorasi harapan dan impian mereka baik untuk diri mereka sendiri maupun untuk organisasi. Inilah saatnya orangorang memikirkan hal-hal besar dan berpikir out of the box serta membayangkan hasil-hasil yang ingin dicapai.

Design, pada tahap ini, orang mulai merumuskan strategi, proses dan sistem, membuat keputusan dan mengembangkan kolaborasi yang mendukung terwujudnya perubahan yang diharapkan. Pada tahap ini semua hal positif di masa lalu ditransformasi menjadi kekuatan untuk mewujudkan perubahan yang diharapkan (dream).

Destiny, Tahap ini adalah tahap dimana setiap orang dalam organisasi mengimplementasikan berbagai hal yang sudah dirumuskan pada tahap Design. Tahap ini berlangsung ketika organisasi secara kontinyu menjalankan perubahan, memantau perkembangannya, dan mengembangkan dialog, pembelajaran dan inovasi-inovasi baru.

Setelah menemukelani aset, memobilisasi aset, tak kalah pentingnya juga ada salah satu prinsip ABCD yaitu kemitraan, maka proses pendampingan masyarakat di desa Metesih Kecamatan Jiwan ini tidak lepas dari kerjasama yang saling menguntungkan yaitu dengan menggandeng berbagai instansi atau organisasi dan komunitas yaitu, UIN Sunan Ampel Surabaya, Pemkab Madiun, Disas Pertanian, Kecamatan Jiwan, Desa Metesih dan Kelompok Wanita Tani Desa Metesih, kelompok 
pengajan, PKK dan sebagainya. Karena kegiatan-kegiatan KWT selalu diikuti pula oleh kelompokkelompok organisasi yang ada di desa itu.

Tabel 1. Matriks Pelaksanaan ABCD

\begin{tabular}{|c|c|c|c|c|}
\hline Tahap & Tujuan & Kegiatan & Jadwal & Bukti \\
\hline \multirow[t]{3}{*}{ Inkulturasi } & $\begin{array}{l}\text { Komunitas } \\
\text { mengetahui maksud } \\
\text { kehadiran Tim } \\
\text { pengabdian }\end{array}$ & $\begin{array}{l}\text { Silaturrahmi ke Kepala } \\
\text { Desa, Toga (Tokoh } \\
\text { agama) dan Tomas } \\
\text { (tokoh masyarakat) } \\
\text { Pengurus PKK, KWT, } \\
\text { Kelompok Pengaiian, } \\
\text { Muslimat, NU, jamaah } \\
\text { musholla tokoh } \\
\text { masvarakat }\end{array}$ & $\begin{array}{l}\text { Minggu ke-2 } \\
\text { Bulan Juli } 2018\end{array}$ & $\begin{array}{l}\text { Catatan } \\
\text { Lapangan } \\
\text { dan foto }\end{array}$ \\
\hline & $\begin{array}{l}\text { Munculnya } \\
\text { kepercayaan dari } \\
\text { komunitas terhadap } \\
\text { tim }\end{array}$ & $\begin{array}{l}\text { Mengikuti majelis taklim, } \\
\text { mengajar di TPQ, } \\
\text { mengajar BTQ, ikut kerja } \\
\text { bakti }\end{array}$ & $\begin{array}{l}\text { Minggu ke-3 } \\
\text { Bulan Juli s.d. } \\
\text { Minggu ke-2 } \\
\text { Bulan Agustus } \\
2018\end{array}$ & $\begin{array}{l}\text { Catatan } \\
\text { Lapangan } \\
\text { dan foto }\end{array}$ \\
\hline & $\begin{array}{l}\text { Tim pengabdian, } \\
\text { memfasilitasi } \\
\text { kelompok masyarakat } \\
\text { yang ada sebagai core } \\
\text { group }\end{array}$ & $\begin{array}{l}\text { FGD untuk mencapai } \\
\text { meeting of mind pada KWT }\end{array}$ & $\begin{array}{l}\text { Minggu } 1 \text { dan } 2 \\
\text { bulan Agustus }\end{array}$ & $\begin{array}{l}\text { Catatan } \\
\text { Lapangan } \\
\text { dan foto }\end{array}$ \\
\hline Discovery & $\begin{array}{l}\text { Tim pengabdian } \\
\text { mengidentifikasi asset } \\
\text { dan potensi desa }\end{array}$ & $\begin{array}{l}\text { Melakukan pemetaan } \\
\text { asset melalui fgd dan } \\
\text { interview }\end{array}$ & $\begin{array}{l}\text { Minggu ke-3 } \\
\text { Bulan Juli } 2018\end{array}$ & $\begin{array}{l}\text { Catatan } \\
\text { Lapangan } \\
\text { dan foto }\end{array}$ \\
\hline \multirow[t]{2}{*}{ Design } & $\begin{array}{l}\text { Mengetahui asset yang } \\
\text { dimiliki }\end{array}$ & $\begin{array}{l}\text { Mensosialisasikanhasil } \\
\text { pemetaan asset kepada } \\
\text { masyarakat dan aparat } \\
\text { desa }\end{array}$ & $\begin{array}{l}\text { Minggu ke-4 } \\
\text { Bulan Juli } 2018\end{array}$ & $\begin{array}{l}\text { Catatan } \\
\text { Lapangan } \\
\text { dan foto }\end{array}$ \\
\hline & $\begin{array}{l}\text { Mengidentifikasi } \\
\text { peluang }\end{array}$ & $\begin{array}{l}\text { Low hangng Fruit } \\
\text { Mengidentifikasi peluang } \\
\text { dan skala prioritas }\end{array}$ & & \\
\hline Define & $\begin{array}{l}\text { Terlaksananya } \\
\text { prioritas program } \\
\text { kerja }\end{array}$ & $\begin{array}{l}\text { Memfasilitasi } \\
\text { pelaksanaan program } \\
\text { pilihan masyarakat }\end{array}$ & $\begin{array}{l}\text { Minggu ke-1 } \\
\text { Bulan Agustus } \\
2018\end{array}$ & $\begin{array}{l}\text { Catatan } \\
\text { Lapangan } \\
\text { dan foto }\end{array}$ \\
\hline Refleksi & $\begin{array}{l}\text { Mengetahui sejauh } \\
\text { mana Program } \\
\text { membawa dampak } \\
\text { perubahan }\end{array}$ & $\begin{array}{l}\text { Melakukan monitoring } \\
\text { kegiatan }\end{array}$ & $\begin{array}{l}\text { Minggu ke-3 } \\
\text { Bulan Agustus } \\
2018\end{array}$ & $\begin{array}{l}\text { Hasil } \\
\text { monitoring } \\
\text { dan jurnal } \\
\text { refleksi }\end{array}$ \\
\hline
\end{tabular}




\section{Hasil dan Diskusi}

Sesuai dengan metode dan teknik yang dijelaskan diatas proses pendampingan masyarakat KWT Desa Metesih sebagai berikut :

\section{Inkulturasi}

Tahapan awal merupakan tahap inkulturasi. Dimana mahasiswa mulai beradaptasi dan menyesuaikan diri, live in dengan masyarakat, strategi awal yakni mulai dengan perkenalan dengan berkunjung ke rumah dari beberapa warga yang ada di daerah tempat tinggal mahasiwa KKN hingga berkunjung di rumah-rumah dusun lainnya. Mulai dari stakeholder dari beberapa organisasi atau kelompok masyarakat hingga anggotanya, TOGA (tokoh agama) dan TOMAS (tokoh masyarakat) merupakan tokoh kunci yang dikunjungi.

Selain itu, pendekatan ini juga di upayakan untuk dapat menyatu dan bergabung menjadi satu dengan masyarakat. Tentu saja dengan cara-cara mengikuti beberapa kegiatan yang memang menjadi rutinitas masyarakat sekitar. Kegiatan yang dilakukan dalam proses ini yakni, kunjungan door to door, kegiatan yasinan rutinan, undangan pengajian rutinan, ikut dalam kegiatan warga membajak sawah, mengikuti rapat-rapat desa, mengikuti kegiatan ibu-ibu PKK, mengajar TPA di Dusun Koci dan Dusun Ngepoh, mengajar BTQ di SDN Metesih 03 dan PAUD Desa Metesih, kerja bakti pembuatan saluran irigasi.

\section{Discovery}

Tahapan ini, merupakan tahapan yang berusaha untuk menemukenali asset-aset yang di ada Desa Metesih. Ada berbagai macam asset yang terdapat di masyarakat yang kami temukan melalui wawancara apresiatif maupun forum-forum santai. Forum-forum tersebut tentu saja diawali dengan forum-forum non formal, dimana lokasi percakapan hingga waktu yang memang tidak di rencanakan sebelumnya. Tahapan ini merupakan tahapan paling penting, tahapan ini berusaha untuk menemukenali potensi-potensi yang ada di masyarakat. Sehingga masyarakat mengetahui bahwa masih banyak potensi yang belum dimaksimalkan di Desa Metesih. Sehingga adanya pemaksimalan potensi tersebut perlu dilakukan.

Dalam tahapan ini, aset-aset desa dapat di temukenali mulai dari proses sebelumnya yakni inkulturasi bersama masyarakat. Menemukenali potensi yang ada di Desa metesih ini, tentu saja menggunakan berbagaimacam tehnik. Salah satunya yakni dengan cara diskusi bersama masyarakat. Dari hasil diskusi maka ditemukan potensi yang muncul, mulai dari aset fisik, aset sumber daya alam, aset institusi aaset sosial dan sebagainya. 


\section{ENGAGEMENT}

Gurnal Pengabdian Kepada Masyarakat

ISSN : 2579-8375 (Print)

ISSN : 2579-8391 (Online)

Salah satu aset dari masyarakat yang potensial dan perlu didampingi untuk memastikan berkembangnya aset tersebut adalah aset institusi atau organisasi Kelompok Wanita Tani (KWT), dimana kelompok ini pada dasarnya berfokus pada pengelolahan hasil pertanian dan pemanfaatan lahan yang ada. Dari hasil perumusan bersama masyarakat minimnya pengelolaan baik hasil pertanian maupun pekarangan yang ada menjadi salah satu titik atau tantangan yang perlu segera diatasi. Karena dari hasil analisa, potensi sumber daya fisik yang ada, dimasing-masing rumah di desa Metesih pasti memiliki lahan pekarangan, baik lahan pekarangan yang luas maupun lahan pekarangan yang sempit. Pemanfaatan ini jika dikembangkan tentu saja menjadi salah satu alternatif mulai dari peningkatan skill dari SDM yang ada sampai pada peningkatan perekonomian masyarakat.

Dalam persepektif $A B C D$ ada dua asset yang bisa dimobilisasi sekaligus yaitu pertama aset pekarangan atau lahan yang melimpah hampir setiap rumah memilikinya, kedua aset organisai yaitu kelompok Wanita Tani (KWT). Sebagai aset atau potensi yang ada, yakni banyaknya lahan pekarangan yang minim pemanfaatannya dan memaksimalkan peran serta fungsi Kelompok Wanita Tani. (KW'T), maka peningkatan dari kedua potensi itu, menjadi fokus dari kegiatan yang akan dirumuskan.

KWT memiliki pengaruh yang besar di dalam masyarakat, juga bagi kelompok-kelompok organisasi lain seperti dalam diagram Venn di bawah ini:

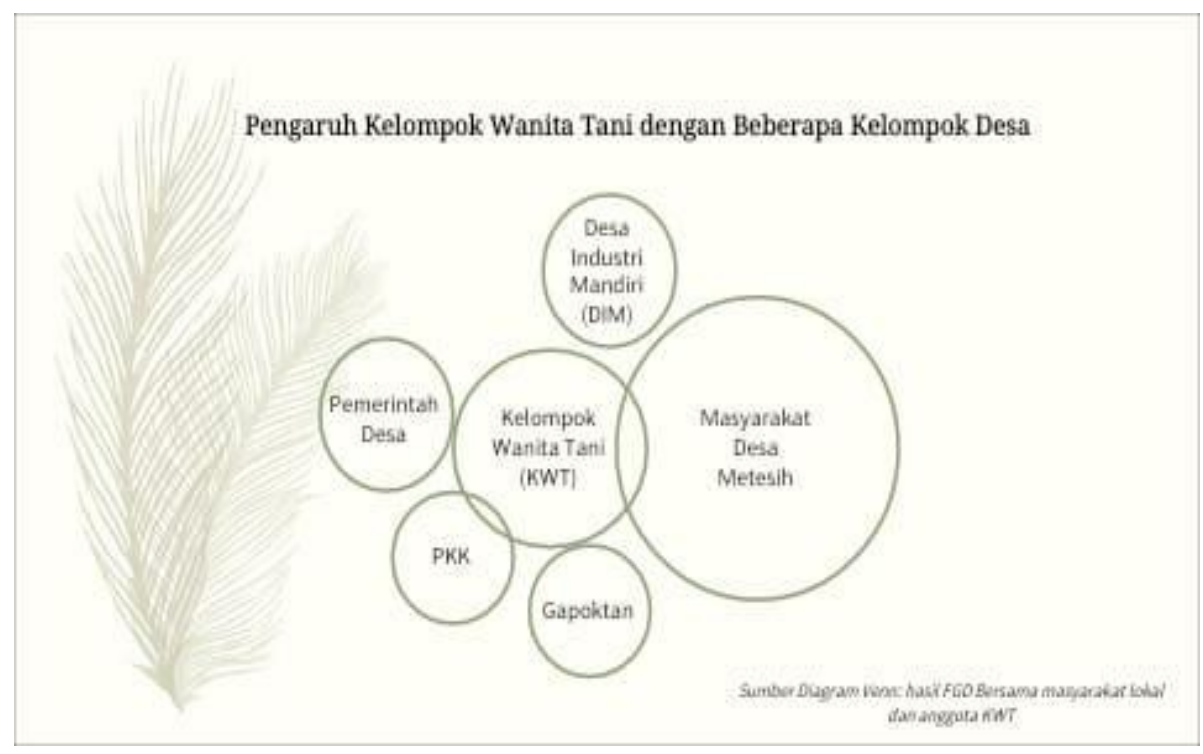

Gambar 2. Diagram Venn Pengaruh Kelompok Wanita Tani

Dari gambar di atas diketahui bahwa KWT adalah salah satu kelompok organisasi yang berpengaruh di desa, karena kelompok wanita tani memang berangkat dari masyarakat anggotaanggotanya bahkan pengurusnya dari masyarakat desa setempat, sehingga kegiatan-kegiatan yang 


\section{ENGAGEMENT}

Jurnal Pengabdian Kepada Masyarakat

ISSN : 2579-8375 (Print)

ISSN : 2579-8391 (Online)

ada merupakan kegiatan yang di peruntukkan bagi masyarakat. Diantara tujuan KWT ini untuk mengembangkan kemampuan dan peningkatan sumber daya manusia yang pada akhirnya akan menambah pendapatan masyarakat.

KWT dengan kelompok PKK juga menunjukkan hubungan yang dekat bahkan ada irisan antara kedua organisasi kelompok itu, karena sebagian anggota KWT adalah anggota PKK dari pokja 3 yang membidangi bidang pertanian sehingga kegiatan-kegiatan bisa kolaborasi dan saling mendukung. Secara struktural KWT merupakan bagian dari gapoktan. Tetapi tidak membatasi ruang gerak KWT sebagai pengelolah hasil pertanian. Karena gapoktas sendiri lebih berfoksu pada alternatif teknologi mengenai pertanian. Sehingga meski dalam satu naungan yakni di bawah BPD, akan tetapi fungsi dari keduanya berbeda namun selaras.

Desa Industri Mandiri (DIM) mempunyain relasi yang cukup kuat dengan KWT, pada awalnya DIM merupakan bagian dari program yang ditawarkan desa melalui organisasi independen. DIM sendiri memiliki keterkaitan dengan KW'T, karena adanya persamaan visi dan misi, dimana DIM berfokus pada teknologi pertanian juga berfokus untuk membuka lapangan pekerjaan yang dibuka guna memenuhi kebutuhan pertanian. Hal ini tentu saja selaras dengan tujuan dari KWT. Sehingga kedua belah pihak ini melakukan kerjasama untuk membangun masyarakat yang sejahtera dan mandiri.

\section{Dream}

Dalam tahap ini, tentu masih berhubungan dengan tahap sebelumnya, dimana setelah menemukenali potensi yang ada maka muncullah harapan-harapan yang di inginkan oleh masyarakat. Pada tahap ini, setiap orang mengeksplorasi harapan dan impian mereka yang merupakan harapan bersama maupun individu untuk di wujudkan bersama-sama. Maka perumusan gerakan-gerakan perubahan akan muncul dalam tahap ini. Harapan utama dari masyarakat tentu saja meningkatnya perekonomian dengan memanfaatkan pekarangan yang mereka miliki.

Dari hasil diskusi dengan masyarakat ternyata sebelumnya kegiatan pemanfaatan lahan telah pernah dilakukan, mulai dari menanam tanaman toga, tanaman kelengkeng, pisang, mangga, dan masih banyak lainnya, namun seiring berkembangnya waktu banyak warga yang enggan untuk menanami lagi pekarangannya dengan berbagai alasan.

Maka saatnyalah masyarakat bangkit untuk mengulangi sukses masa lalu dengan lebih inovatif dan kreatif yang menghasilkan makanan berbagai macam produk siap saji apalagi di kota Madiun sedang diadakan pameran besar-besaran, kegiatan ini digerakkan oleh kota Madiun sesuai 
dengan visi Kota Madiun yakni menjadi Kota Gadis (Perdangan dan Industri), maka hal ini menambah semangat masyarakat agar bisa memenuhi kriteria untuk dimasukkan dalam pameran tersebut.

Setelah mapping aset maka ditemukan adanya aset yang sangat potensial untuk menggerakkan dan menggapai mimpi-mimpi masyarakat yaitu organisasi KW'T yang telah dimiliki oleh masyarakat Metesih, namun pada saat itu kepengurusan KWT sedang vakum kurang lebih satu tahun karena ada transisi kepemimpinan. Untuk itulah ada kesepakatan bersama antara masyarakat kepala desa dan perangkatnya serta mahasiswa untuk merevitalisasi KWT.

\section{Design}

Dalam tahap ini, dirumuskan strategi untuk mencapai harapan yang diinginkan. Perumusan program, dilakukan secara bersama-sama oleh KW'T, kelompok pengajian, PKK dan kelompok mahasiswa. Proses perumusan ini berjalan lancer dengan mengsusung tema "Revitalisasi Kelompok Wanita Tani melalui Pemanfaatan Lahan Pekarangan”. Hal ini tentu saja memiliki beberapa alasan dan landasan mengapa program tersebut yang dipilih.

Reviltalisasi kelompok wanita tani ini sangat penting karena KWT merupakan organisasi kelompok masyarakat yang akan peningkatan skill mereka mereka mendapatkan pelatihan dari dinas pertanian dan dinas ketahanan pangan kabupaten Madiun sehingga nantinya akan dapat menggerakkan kegiatan-kegiatan yang menunjang peningkatan perekonomian. Revitalisasi ini di tuangankan dalam kegiatan pemanfaatan lahan pekarangan yang ada, dimana pemanfaatan ini menjadi media atau program pertama kelompok wanita tani menuju kebersamaan dan kesolidan kelompok.

Fokus dari KWT ini adalah pada penanaman tanaman yang dapat dikonsumsi sendiri terlebih dahulu seperti bumbu dapur, cabe, tomat dengan harapan dapat mengurangi ketergantungan dari luar desa. Untuk media tanam bagi lahan pekarnagan yang luas cukup memanfaatkan tanah yang tersedia dilahan pekarangan rumah namun untuk rumah yang memiliki lahan pekarangan sempit maka media yang ditawarkan yakni menggunakan media kokopit yang memanfaatkan serabut kelapa sebagai alat tanamnya.

Maka untuk implementasi dari harapan-harapan diatas dilaksanakan kegiatan-kegiatan sebagai berikut :

a) FGD Kelompok Wanita Tani

b) Pembuatan pupuk organik dari kotoran kambing

c) Pemindahan tanaman (bibit) ke Polybag 


\section{ENGAGEMENT}

Gurnal Pengabdian Kepada Masyarakat

ISSN : 2579-8375 (Print)

ISSN : 2579-8391 (Online)

d) Pembagian bibit ke masing-masing dusun

e) Proses penanaman pekarangan oleh masyarakat

\section{Destiny}

Dalam tahap ini merupakan proses implementasi dari program yang telah dirumuskan dalam tahap design. Dalam tahap ini mulai dari pembelian bibit kurang lebih sekitar 600 bibit dengan rincian 300 bibit cabe dan 300 bibit tomat. Pembuatan pupuk organik, juga di buat sendiri tanpa membeli bahan baku dari luar.

Kegiatan awal dalam porgram ini membuat pupuk, pemindahan tanaman, penyiraman tanaman, hingga nanti siap di tanam dilahan pekarangan. Pembuatan pupuk yang membutuhkan pasir, kotoran kambing, serutan kayu, gabah, dan air dilakukan jauh-jauh hari sebelum pembelian bibit. Karena proses pembusukan pupuk merupakan salah satu porses yang membutuhkan waktu hingga 3 hari.

Setelah pembuatan pupuk, maka tahap selanjutnya yakni pemindahan bibit ke polybag. Dari polybag yang kosong di isi dengan pupuk yang telah dibuat sebelumnya kemudian bibit tanaman dimasukkan kedalam polybag. Setiap harinya (pagi dan sore) tanaman di siram dengan air yang telah dicampur oleh beberapa obat pertanian. Setelah sekitar 3 hari, tanaman yang ada di polybag siap untuk ditanam di lahan pekarangan.

\section{a) FGD Kelompok Wanita Tani}

Kegiatan ini di pimpin langsung oleh ketua KWT dan perwakilan mahasiswa selaku pengarah acara dalam kegiatan tersebut semua anggota mulai menyampaikan satu persatu harapan kedepan untuk masa depan kelompok wanita tani, meski belum keseluruhan yang menyampaikan pendapat namun dari pengurus mulai mengajak anggota lain untuk membuat perubahan sampai yakin bahwa mereka bagian dari perubahan desa menuju desa yang lebih baik dan makmur.

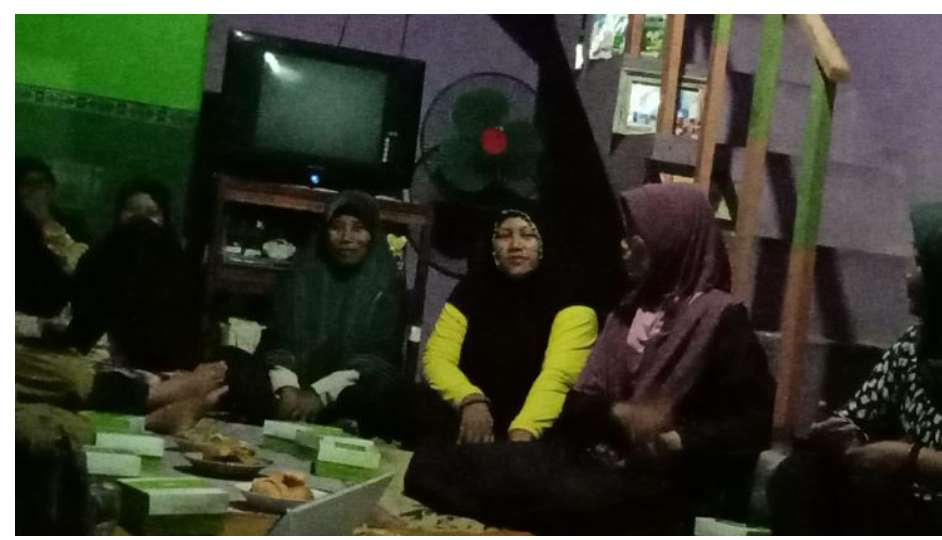

Gambar 3. FGD Kelompok Wanita Tani 


\section{ENGAGEMENT}

Gurnal Pengabdian Kepada Masyarakat

ISSN : 2579-8375 (Print)

ISSN : 2579-8391 (Online)

Hingga merumuskan beberapa kegiatan seperti pemanfaatan lahan pekarangan sebagai agenda awal kelompok. Dan mencoba menunjukkan satu persatu job disk hingga pengelolaan kegiatan. Sehingga fungsi dari kelompok wanita tani dapat berfungsi sebagaimana mestinya.

Selanjutnya mereka mendiskusikan bagaimana kelanjutan dan prospek kedepan kelompok tani setelah mereka mulai menemukenali aset yang mereka miliki agar mereka merasa memiliki bersama dan bisa dimobilisasi untuk kepentingan bersama.

\section{b) Pembuatan Pupuk Organik dari Kotoran Kambing}

Kegiatan ini merupakan awal dari program yang rumuskan, sesuai dengan prinsip ABCD adalah memanfaatkan kekuatan lokal atau aset lokal, maka mulai dari media hingga penunjang kegiatan di usahakan semaksimal mungkin menggunakan bahan baku yang ada di desa misalnya pupuk organik yang bahan bakunya tersedia di Desa Metesih karena banyak dari masyarakat di Desa Metesih memiliki peternakan baik kambing maupun sapi.

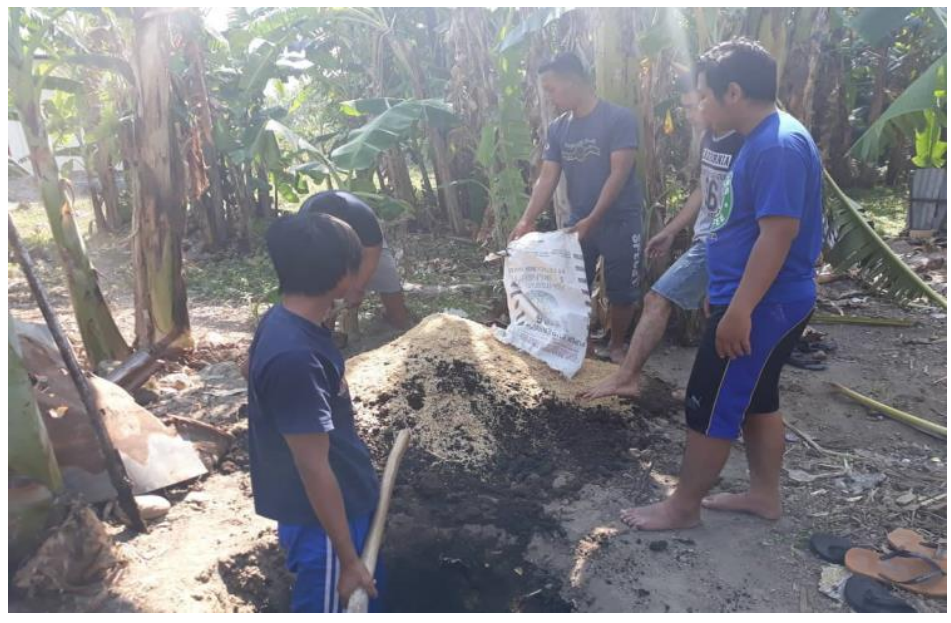

Gambar 4. Pembuatan Pupur Organik

Pembuatan pupuk organik bagi masyarakat tidak terlalu sulit apalagi bahan baku sudah tersedia di desa, dengan cara mencampur seluruh bahan kemudian disiram air dan di tutup terpal selanjutnya di tunggu pembusukkanya sekitar 3 hari.

Tingkat pastisipasi kegiatan ini sangat tinggi mereka yang datang tidak hanya KWT saja namun ibu-ibu dari kelompok pengajian per-RT juga turut berpartisipasi. Sehingga kegiatan semacam ini dapat dilakukan oleh siapapun.

\section{c) Pemindahan bibit Tanaman ke Polybag}

Selanjutnya setelah pupuk yang telah di busukkan jadi maka langkan berikutnya adalah memindahkan bibit ke dalam polybag kegiatan ini tidak memerlukan pemateri atau nara sumber 


\section{ENGAGEMENT}

Jurnal Pengabdian Kepada Masyarakat

ISSN : 2579-8375 (Print)

ISSN : 2579-8391 (Online)
This work is licensed under a Creative Commons Attribution-ShareAlike 4.0 International License. CC BY SA

dari luar karena dari anggota KWT banyak yang telah menadapatkan skill dalam pelatihan dari dinas terkait.

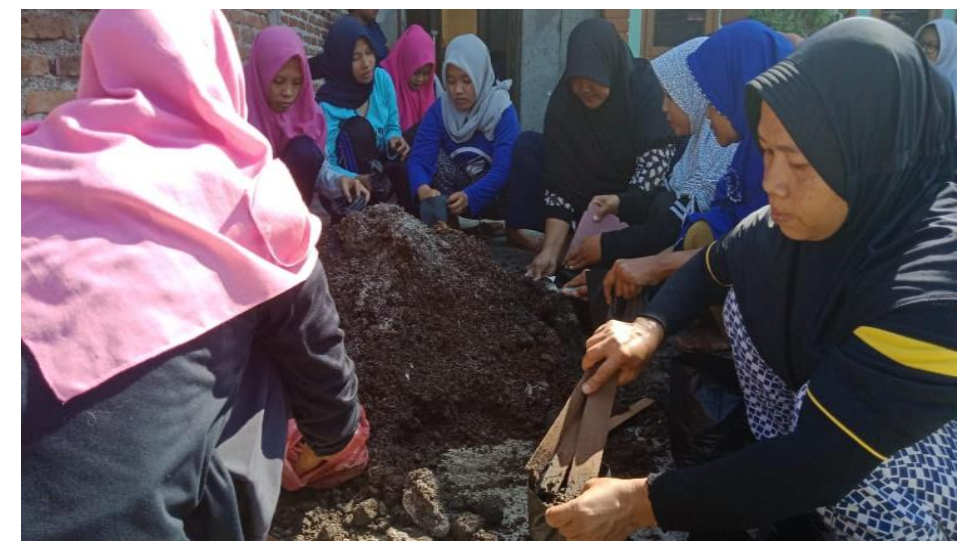

Gambar 5. Mengisi Polybag dengan Tanah dan Pupuk

Penataan mulai dari tata cara mencampur tanah dengan pupuk hingga jumlah atau takaran pupuk dan tanah yang masukkan. Selain itu, jumlah bibit yang di masukkan di masing-masing polybag juga di tata. Pengetahuan-pengetahuan seperti ini yang perlu dikembangkan di masyarakat sehingga ada sharing knowledge diantara mereka.

Tanaman yang telah selesai di masukkan dan dibedakan sesuai jenis bibit yang telah di sediakan. Ada dua bibit tanaman yang tersedia, yaitu cabai dan tomat, dari masing-masing tanaman dikelompokkan dan di letakkan di lokasi yang memiliki cukup memiliki sinar matahari.

\section{d) Pembagian Bibit di Masing-masing Dusun}

Kegiatan selanjutnya yakni membagikan bibit di masing-masing dusun dengan harapan seluruh masyarakat dapat berpartisipasi dalam pemanfaatan lahan pekarangan. Kegiatan ini juga diharapakan dapat menjadi stimulasi untuk dikembangkan di masing-masing dusun dan anggota KWT yang awalnya dari RT tertentu bisa berkembang secara merata ke masing-masing RT.

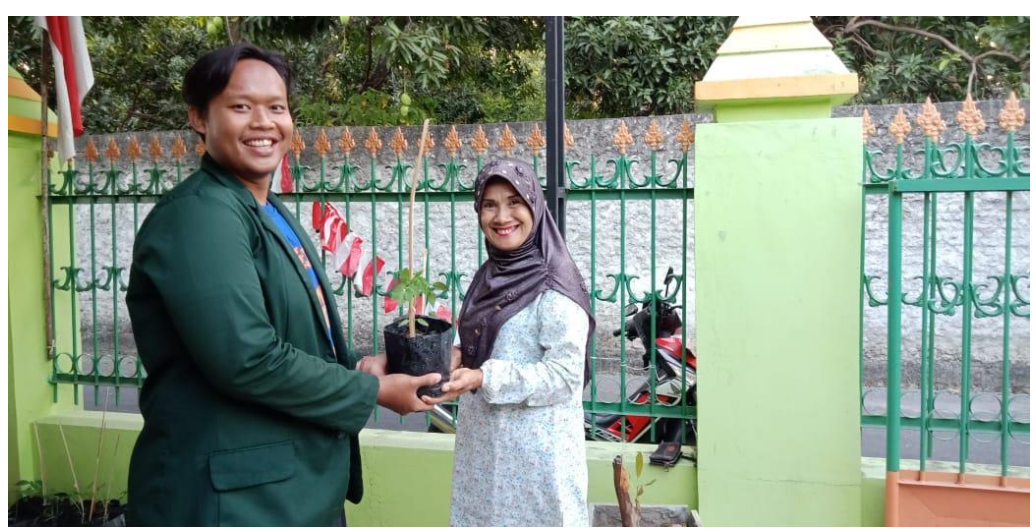

Gambar 6. Distribusi Tanaman

Volume 2, Number 2, November 2018| 218 Revitalisasi Kelompok Wanita Tani (KWT) melalui Pemanfaatan Pekarangan Rumah di Desa Metesih Kecamatan Jiwan Kabupaten Madiun 


\section{ENGAGEMENT}

Gurnal Pengabdian Kepada Masyarakat

ISSN : 2579-8375 (Print)

ISSN : 2579-8391 (Online)

Setelah distribusi bibit dilaksanakan kemudian penanaman serentak oleh masyarakat desa Metesih sekaligus memperkokoh gotong royong desa untuk menuju desa yang memiliki kekuatan potensi dalam penanaman di lahan pekarangan rumah, di masing-masing dusun telah di musyawarahkan penanggung jawab untuk mengelolan dan merawat tanaman tersebut sampai tanaman bisa didirasakan hasilnya oleh seluruh warga sekitar.

\section{Kesimpulan}

\section{Refleksi}

Selama proses kegiatan selama satu bulan dalam memfasilitasi masyarakat khususunya KW'T terasa ada beberapa nilai yang sangat berharga dari kita semua diantaranya kesadaran bahwa masyarakat yang awalnya hanya berfikiran potensi berada di desa lain ada di kota lain, setelah AI dan Discovery maka mereka betul-betul menyadari bahwa kita memang memiliki sesuatu.

Nilai berikutnya adalah kebersamaan yang dimiliki masyarakat desa Metesih dengan bersatu padu baik dalam intern kelompok maupun antar kelompok maka semua terasa ringan, nilai lain yang tak kalah pentingnya adalah kemitraan, begitu besar artinya relasi jaringan yang terjalin selama ini antara KWT, PKK, kelompok pengajian, Dinas Pertanian, Dinas Ketahanan Pangan pemerintah Desa Tokoh masayarakat tokoh agama dan sebagainya, dengan memaksimalkam kemitraan maka akan membuka jalan yang luas untuk memobilisasi aset yang dimiliki masyarakat.

Akhirnya Change atau perubahan terjadi di masyarakat baik perubahan non fisik sepert maindset, pola pikir maupun perubahan-perunahan yang lain seperti ekonomi, sosial kebersamaan dan sebagainya. Beberapa indikator perubahan yang terjadi pada masyarakat seperti dalam tabel di bawah ini :

Tabel 2. Indikator Perubahan

\begin{tabular}{ll}
\hline \multicolumn{1}{c}{ Change } & \multicolumn{1}{c}{ Examples } \\
\hline Kapasitas Organisasi & - Meningkatnya nilai kerja sama \\
& - Meningkatnya nilai demokrasi dan inclusive groups \\
& - luar \\
& - Peningkatnya motivati untuk mobilisasi sumber daya \\
& - dan lain lain \\
\hline Sikap & - Menghargai nilai-nilai positif terdahulu yang \\
& - Berlupakan \\
& - dan lain lain \\
\hline Assets nyata & - Rumah KWT sebagai pusat kegiatan \\
&
\end{tabular}




\section{ENGAGEMENT}

Jurnal Pengabdian Kepada Masyarakat

ISSN : 2579-8375 (Print)

ISSN : 2579-8391 (Online)
This work is licensed under a Creative Commons Attribution-ShareAlike 4.0 International License.

\begin{tabular}{ll}
\hline & - Pupuk Organik \\
& - Macam-maca tanaman di pekarangan \\
& - Hasil produk tanaman \\
& - Meningkatnya kesuburan tanah pekarangan \\
& - dan lain lain \\
\hline Pendapatan hasil produksi & - Penjualan bibit tanaman di desa \\
\hline Menambah simpanan tunai & - Penjualan hasil tanaman \\
\hline atau berupa bahan & - Saving belanja rumah tangga \\
\hline
\end{tabular}

\section{Daftar Referensi}

Dureau, Christopher. Pembaru Dan Kekuatan Lokal Untuk Pembangunan. TT: Australian Community Development and Civil Society Strengthening Scheme (ACCESS) Phase II, 2013.

Irawan, Abdullah. Sangkan Peran Jender. Yogyakarta: Pustaka palajar untuk PKK UGM, 1997.

Mathie, Alison, and Gord Cunningham. "Mobilizing Assets for Community-Driven Development." Participant manual (2008).

Munandar, SC Utami.. "Kemitrasejajaran, Perspektif Psikologis." In Wacana Perempuan Dalam Keindonesiaan Dan Kemodernan, edited by Bainar. Jakarta: Cides. Munandar SC Utami, 1995.

Salahuddin, Nadhir. "Panduan KKN ABCD UIN Sunan Ampel Surabaya Asset Based Community-Driven Development (ABCD)." Surabaya: LP2M UIN Sunan Ampel Surabaya, 2015.

Subiyantoro, Eko Bambang. Sensitivitas Gender Kebijakan Pemerintaban Sby. Jakarta: The Indonesian Institute, 2005. http://www.theindonesianinstitute.com/wp-content/uploads/2014/02/11POLICY-ASSESSMENT-Sensitivas-Gender-oleh-Eko-Bambang-Subiyantoro-Juni2005.pdf.

Zubaedi. Pengembangan Masyarakat. Jakarta: Kencana Prenada Media Group, 2013. 